\section{Risk factors for breast cancer: a systematic review of studies with female samples among the general population in Brazil}

\author{
Fatores de risco para câncer de mama: \\ uma revisão sistemática de estudos com amostras \\ de mulheres da população geral no Brasil
}

Valéria Fernandes de Souza Pinho ${ }^{1}$ Evandro da Silva Freire Coutinho ${ }^{2}$

\footnotetext{
1 Centro Nacional de Transplante de Medula Óssea, Instituto Nacional de Câncer, Rio de Janeiro, Brasil. 2 Escola Nacional de Saúde Pública, Fundação Oswaldo Cruz, Rio de Janeiro, Brasil.

Correspondence V. F. S. Pinho Centro Nacional de Transplante de Medula Óssea, Instituto Nacional de Câncer. Av. Feliciano Sodré 242, apto. 411, Teresópolis, RJ 25963-081, Brasil. vdesouzapinho@yahoo.com.br
}

\begin{abstract}
A systematic review of studies was conducted to determine the characteristics of epidemiological research on risk factors for breast cancer in female samples from the general population in Brazil. Of the 23 articles identified, only 14 were selected for review. Most of the studies were from Southeast Brazil. Three were cross-sectional, conducted in specific populations, and 11 used case-control designs. The sample sizes varied from 40 to 164,269 women. Twenty-nine risk factors were researched, and among these, 11 were investigated in four or more studies. Nulliparity was the most frequent factor, found in 12 of the studies. Prevalence of the factors varied widely among the samples, and since the samples were heterogeneous and the studies presented several methodological limitations, a summary mean was not calculated.
\end{abstract}

Risk Factors; Breast Neoplasms; Review Literature

\section{Introduction}

Breast cancer is the invasive neoplasm with the highest incidence rate and mortality among Brazilian women. From 1980 to 2000, the breast cancer mortality rate increased from 6.14 to 9.64 per 100 thousand women, resulting in a relative increase of $57.0 \%$, that is, posing a major public health problem for the country 1,2 .

The disease has a multi-factor etiology and is one of the most widely studied tumors in terms of its determinants. Epidemiological studies and basic research have identified a series of conditions that can predispose women to breast cancer. Such research is crucial to knowledge of the tumor biology and to identify risk factors and especially habits that can be altered or controlled in the attempt to decrease the number of new cases or deaths from the disease 3 .

The risk factors for breast cancer cover a broad range of conditions, from age to complex genetic alterations. In addition to age, first-degree family history is probably the most widely acknowledged and scientifically proven risk factor. Nevertheless, aspects in the woman's hormonal and childbearing history show evidence of association between the disease and early menarche, late menopause, nulliparity, and late first gestation 4,5 .

Environmental characteristics such as diet and body weight have also been extensively in- 
vestigated in the etiology of breast cancer. Studies conducted in populations from countries in which the incidence is low and who immigrated to high-incidence countries have demonstrated that descendents begin to present an incidence similar to the country where they are residing, raising the hypothesis that hormonal, reproductive, and environmental factors are as important as (or more so than) genetic factors and probably account for the variation in rates between different locations 6,7. This suggests that the use of international estimates for prevalence of risk factors for breast cancer may not be adequate for defining Brazilian health policies, since the populations have different characteristics.

In Brazil, several studies have been done on this topic, and since programs for early detection and health promotion target the general population, we felt the need to critically review these studies, describing their characteristics, the risk factors investigated, and their distributions, thus expanding the knowledge concerning the research on breast cancer epidemiology in Brazilian women.

\section{Material and methods}

From February to December 2002, various literature searches were conducted in the MEDLINE and LILACS databases (available at http://www. bireme.br) in the field "subject descriptor" in the advanced form and with the utilization of the following key words: "breast cancer", "risk factors", and "Brazil". Additional searches were also done in the bibliographic references of the articles identified, in addition to consultations with experts.

The selection aimed to include all articles published from 1966 to 2002 with samples of Brazilian women and with the following characteristics: cross-sectional studies with samples of diverse populations, as well as casecontrol and follow-up studies. In the latter two study designs, the focus was exclusively on the comparison groups, since if they are well-selected they can represent the basic populations in which the cases originated 8 . Excluded from the review selection were cross-sectional studies whose samples only included confirmed breast cancer cases, studies whose results do not present the distribution of risk factors in the comparison groups, and repeated publications, in which case whenever possible we preferred the more complete studies in terms of presenting the frequencies of risk factors investigated.
Data were extracted through an adaptation of the Qualitative Assessment Questionnaire proposed by Moreno \& Lopes 9 , and the following topics and respective variables were reviewed:

- Identification of studies: authors, city, year, and language of the publication;

- Study characteristics: design and data collection method;

- Sample characteristics: size, mean age and/ or age bracket, and selection methods. In the studies on associations, these characteristics were reviewed only in the comparison groups, as specified previously;

- Distribution of the risk factors investigated: we considered all the factors whose frequencies were specified in the study results. For those in which only absolute frequency was presented, the proportion of factors was calculated.

Data were managed using SPSS for Windows, version 9.0, calculating the frequencies of the variables. Distributions of the risk factors that were investigated in four or more studies were presented and the prevalence rates were specifically reviewed again by the same observer some sixty days after the first review, and intra-observer reliability was estimated using the intra-class correlation coefficient.

\section{Results}

The literature search led to 23 studies. After reading the studies, nine were excluded: five because they were repeat publications 10,11,12, 13,14; two were international multi-center studies originating from the same database and which failed to present the data from the Brazilian sample separately 15,16 ; one failed to present the distribution of risk factors in the comparison groups 17; and one because the sample consisted only of confirmed breast cancer cases 18. The review of references in the articles identified above failed to identify new contributions.

The final selection thus included 14 studies, one of which evaluated two samples at different times 19, while in another case two studies used the same sample at different times and with different approaches 20,21 , and this also resulted in 14 representative samples.

\section{Study characteristics}

Table 1 shows the principal characteristics of the studies reviewed. In addition to these, we found that nine studies were published in Brazilian periodicals, two in international journals, 
General characteristics of studies reviewed. Risk factors for breast cancer in Brazil.

\begin{tabular}{|c|c|c|c|c|c|c|c|c|c|c|}
\hline No. & Authors & Year & Language & City, State* & Design & $\begin{array}{l}\text { Data } \\
\text { collection } \\
\text { method }\end{array}$ & $\begin{array}{l}\text { Sample } \\
\text { size }\end{array}$ & $\begin{array}{l}\text { Age bracket } \\
\text { and/or } \\
\text { mean age }\end{array}$ & $\begin{array}{l}\text { Sample } \\
\text { base }\end{array}$ & $\begin{array}{l}\text { Sample } \\
\text { selection }\end{array}$ \\
\hline 1 & Osanai 43 & 1984 & Portuguese & $\begin{array}{l}\text { Rio de } \\
\text { Janeiro, RJ }\end{array}$ & Case-control & $\begin{array}{l}\text { Review of } \\
\text { patient } \\
\text { histories }\end{array}$ & 295 & 24 to 94 & Hospital & NS \\
\hline 2 & Hardy et al. 32 & 1989 & Portuguese & $\begin{array}{l}\text { Campinas, } \\
\text { SP }\end{array}$ & Case-control & Interview & 348 & NS & $\begin{array}{l}\text { Hospital and } \\
\text { specialized } \\
\text { clinic }\end{array}$ & NS \\
\hline 3 & Kalache et al. 22 & 1993 & English & $\begin{array}{l}\text { Fortaleza, } \\
\text { CE and } \\
\text { Recife, PE }\end{array}$ & Case-control & Interview & 509 & NS & Hospital & Recruitment \\
\hline 4 & Barros et al. 44 & 1996 & Portuguese & $\begin{array}{l}\text { São Paulo, } \\
\text { SP }\end{array}$ & Case-control & Blood tests & 56 & 52.59 & Hospital & NS \\
\hline 5 & Mendonça 20 & 1997 & Portuguese & $\begin{array}{l}\text { Rio de } \\
\text { Janeiro, RJ }\end{array}$ & Case-control & $\begin{array}{l}\text { Interview and } \\
\text { blood tests }\end{array}$ & 377 & 56.6 & Hospital visitors & Recruitment \\
\hline 6 & Souza et al. 33 & 1998 & Portuguese & $\begin{array}{l}\text { Novo } \\
\text { Hamburgo, } \\
\text { RS }\end{array}$ & Case-control & $\begin{array}{l}\text { Interview and } \\
\text { mammogram }\end{array}$ & 222 & 54 & $\begin{array}{l}\text { Radiological } \\
\text { diagnosis clinic }\end{array}$ & Random \\
\hline 7 & Lima \& Falk 25 & 1998 & Portuguese & Recife, PE & $\begin{array}{l}\text { Cross- } \\
\text { sectional }\end{array}$ & $\begin{array}{l}\text { Computer } \\
\text { consultation }\end{array}$ & 164,269 & $\begin{array}{l}<20 \\
\text { to }>70\end{array}$ & Hospital & Census \\
\hline 8 & $\begin{array}{l}\text { Lamas \& } \\
\text { Pereira } 26\end{array}$ & 1999 & Portuguese & Brasília, DF & $\begin{array}{l}\text { Cross- } \\
\text { sectional }\end{array}$ & $\begin{array}{l}\text { Interview and } \\
\text { mammogram }\end{array}$ & 3,209 & NS & $\begin{array}{l}\text { Radiological } \\
\text { diagnosis clinic }\end{array}$ & Census \\
\hline 9 & Matuo et al. 45 & 2000 & English & $\begin{array}{l}\text { Ribeirão } \\
\text { Preto, SP }\end{array}$ & Case-control & $\begin{array}{l}\text { Interview and } \\
\text { blood tests }\end{array}$ & 152 & 35 to 92 & Population & NS \\
\hline 10 & Tessaro et al. 34 & 2001 & Portuguese & Pelotas, RS & Case-control & Interview & 1,020 & 47 & $\begin{array}{l}\text { Hospital and } \\
\text { neighborhood }\end{array}$ & Systematic \\
\hline 11 & 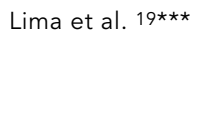 & 2001 & Portuguese & $\begin{array}{l}\text { Aquidauana } \\
\text { and } \\
\text { Anastácio, } \\
\text { MS }\end{array}$ & $\begin{array}{l}\text { Cross- } \\
\text { sectional }\end{array}$ & $\begin{array}{l}\text { Interview, } \\
\text { clinical } \\
\text { examination, } \\
\text { and Pap smear }\end{array}$ & $\begin{array}{l}\text { 1st: } 330 \\
\text { 2nd: } 40\end{array}$ & $\begin{array}{l}1 \text { st: }<20 \\
\text { to }>69 \\
2 \text { nd: } 20 \\
\text { to }>69\end{array}$ & $\begin{array}{l}\text { Indigenous } \\
\text { communities }\end{array}$ & Recruitment \\
\hline 12 & $\begin{array}{l}\text { Vasconcelos } \\
\text { et al. 21\# }\end{array}$ & 2001 & English & $\begin{array}{l}\text { Rio de } \\
\text { Janeiro, RJ }\end{array}$ & Case-control & $\begin{array}{l}\text { Interview and } \\
\text { blood tests }\end{array}$ & 377 & 56.6 & Hospital visitors & Recruitment \\
\hline 13 & $\begin{array}{l}\text { Amorim } \\
\text { et al. } 46\end{array}$ & 2002 & English & $\begin{array}{l}\text { Rio de } \\
\text { Janeiro, RJ }\end{array}$ & Case-control & $\begin{array}{l}\text { Interview and } \\
\text { blood tests }\end{array}$ & 256 & 53.1 & Hospital & Recruitment \\
\hline 14 & Paiva et al. 31 & 2002 & Portuguese & $\begin{array}{l}\text { Juiz de } \\
\text { Fora, MG }\end{array}$ & Case-control & Interview & 76 & NS & Hospital & NS \\
\hline
\end{tabular}

* States: $R J=$ Rio de Janeiro; $S P=$ São Paulo; $C E=$ Ceará; PE = Pernambuco; RS = Rio Grande do Sul;

$\mathrm{DF}=$ Distrito Federal; MS = Mato Grosso do Sul; MG = Minas Gerais.

** In case-control studies, the sample size refers only to the number of controls.

*** Study with two different samples, the first analyzed in 1995 and the second in 1997

\# Study performed with the same sample as in study number 5.

NS = not specified. 
two as final texts in a Master's thesis and Ph.D. dissertation, available in specific libraries, and one was part of a book published by a society to fight cancer. One study was done by researchers from the London School of Hygiene and Tropical Medicine (United Kingdom) 22 and the others by Brazilian researchers.

Only three of the 14 studies were cross-sectional and were based in the following populations: indigenous women, women from a private radiological diagnostic clinic, and women treated at a cancer hospital screening service.

In two cross-sectional studies, the study population consisted of the census of women evaluated during a given time period, and in the third the sample was voluntary, following recruitment. Age was the variable used for matching in ten of the 11 case-control studies. Two studies also matched other characteristics, such as area of residence and hormonal and reproductive variables.

Few studies specified the criteria for inclusion and exclusion of controls, with the exception that the women could not have a personal history of breast cancer. One study excluded women with gynecological or endocrine problems; another excluded pre-menopausal women using hormone replacement therapy; and a third excluded pregnant women or those with diseases possibly related to the use of oral contraceptives.

\section{Risk factors investigated}

A total of 29 risk factors were investigated, but with wide variation in the frequency in the samples. The following risk factors were only investigated in one study each: area of residence, excessive fat intake, high height, serum lipid level, history of benign breast disease, and investigation of polymorphisms. Socio-demographic characteristics like schooling, marital status, and skin color, in addition to lifestyle habits such as smoking and alcohol consumption were included in more studies. Still, the vast majority assessed family history of breast cancer and the women's own hormonal and reproductive history. Nulliparity was the most frequently investigated variable (12 studies).

Eleven risk factors were considered in four or more samples, but their prevalence rates varied greatly (Table 2). In addition, some numeric variables such as age at menarche and age at first gestation used different cutoffs in the various studies, as shown in Table 2. Finally, the analysis of reliability in obtaining these prevalence rates showed an intra-class correlation coefficient of 0.95 (95\%CI: 0.94-0.96).

\section{Discussion}

Knowing the distribution of risk factors for breast cancer in a given population can help identify the groups at greatest risk who would benefit from a systematic program for early detection of the disease. This knowledge is obtained through epidemiological research, principally surveys and cross-sectional studies, which are appropriate designs for estimating the prevalence of an exposure or disease at a given point in time 23,24 . Unfortunately, only three cross-sectional studies were found in this review, and their findings need to be analyzed with caution because they were based in very specific populations.

The first was a survey of women who came for screening at a cancer hospital to evaluate suspicious signs and symptoms. This suggests that some risk factors, not only for breast cancer, but also for other types of tumors, could be overrepresented in this group and leads us to suspect that some of the women may already have had the disease, but without an established diagnosis. Nevertheless this potential bias was not mentioned in the study 25 .

The second cross-sectional study, by Lamas \& Pereira 26, was also a survey of women who came to a private radiological diagnostic clinic. In relation to the specificity of this population, this characteristic led us to note that high socioeconomic status and related co-factors might also be overrepresented in this group. Corroborating this hypothesis, the groups showed other interesting findings, such as $19.0 \%$ of women with a family history of breast cancer and $0.5 \%$ of breast cancer survivors, prevalence rates that were not found in the other studies we reviewed.

The last cross-sectional study contained two small samples of indigenous women, who thus presented very specific characteristics. Unlike the results of the previous study, we highlight the lack of family or personal history of breast cancer among the indigenous women, but this may have been a chance finding. Another limitation of the study, identified by the authors themselves, was that the samples were voluntary, which may have produced a bias in the results, since women who submit spontaneously to screening may have a different perception of their health status as compared to the overall population 19,24 .

The other samples reviewed in the current study were the controls from case-control studies conducted in Brazil and specifically involved three potential limitations. The first relates to the size of these comparison groups, nine out 
Prevalence rates of risk factors investigated in four or more studies.

\begin{tabular}{|c|c|c|c|c|}
\hline Risk factor & Prevalence (\%) & Sample size & Study & Design \\
\hline \multirow[t]{5}{*}{ Marital status single: yes/no } & 4.80 & 377 & Mendonça 20 & Case-control \\
\hline & 5.70 & 348 & Hardy et al. 32 & Case-control \\
\hline & 12.90 & 1,020 & Tessaro et al. 34 & Case-control \\
\hline & 15.30 & 330 & Lima et al. 19 & Cross-sectional \\
\hline & 64.10 & 295 & Osanai 43 & Case-control \\
\hline \multirow[t]{5}{*}{ Skin color white: yes/no } & 44.70 & 76 & Paiva et al. 31 & Case-control \\
\hline & 48.00 & 256 & Amorim et al. 46 & Case-control \\
\hline & 59.00 & 295 & Osanai 43 & Case-control \\
\hline & 80.30 & 152 & Matuo et al. 45 & Case-control \\
\hline & 84.40 & 1,020 & Tessaro et al. 34 & Case-control \\
\hline General family history & 0.00 & 330 & Lima et al. 19 & Cross-sectional \\
\hline \multirow[t]{8}{*}{ of breast cancer: yes/no } & 0.00 & 40 & Lima et al. 19 & Cross-sectional \\
\hline & 3.90 & 256 & Amorim et al. 46 & Case-control \\
\hline & 4.20 & 295 & Osanai 43 & Case-control \\
\hline & 6.50 & 164,269 & Lima \& Falk 25 & Cross-sectional \\
\hline & 9.80 & 377 & Mendonça 20 & Case-control \\
\hline & 12.20 & 1,020 & Tessaro et al. 34 & Case-control \\
\hline & 15.50 & 348 & Hardy et al. 32 & Case-control \\
\hline & 19.00 & 3,209 & Lamas \& Pereira 26 & Cross-sectional \\
\hline First-degree family history & 2.70 & 222 & Souza et al. 33 & Case-control \\
\hline \multirow[t]{3}{*}{ of breast cancer: yes/no } & 3.50 & 348 & Hardy et al. 32 & Case-control \\
\hline & 9.80 & 377 & Mendonça 20 & Case-control \\
\hline & 13.10 & 76 & Paiva et al. 31 & Case-control \\
\hline \multicolumn{5}{|l|}{ Early menarche: yes/no } \\
\hline$<11$ years & 9.00 & 164,269 & Lima \& Falk 25 & Cross-sectional \\
\hline$<12$ years & 12.20 & 295 & Osanai 32 & Case-control \\
\hline$\leq 11$ years & 16.40 & 76 & Paiva et al. 31 & Case-control \\
\hline$\leq 11$ years & 26.30 & 152 & Matuo et al. 45 & Case-control \\
\hline$\leq 11$ years & 29.30 & 3,209 & Lamas \& Pereira 26 & Cross-sectional \\
\hline$\leq 12$ years & 40.60 & 377 & Mendonça 20 & Case-control \\
\hline$\leq 12$ years & 41.40 & 256 & Amorim et al. 31 & Case-control \\
\hline$\leq 12$ years & 42.70 & 1,020 & Tessaro et al. 34 & Case-control \\
\hline$\leq 12$ years & 69.60 & 330 & Lima et al. 19 & Cross-sectional \\
\hline \multirow[t]{7}{*}{ Use of oral contraceptives: yes/no } & 4.00 & 330 & Lima et al. 19 & Cross-sectional \\
\hline & 7.20 & 222 & Souza et al. 33 & Case-control \\
\hline & 9.90 & 3,209 & Lamas \& Pereira 26 & Cross-sectional \\
\hline & 27.00 & 348 & Hardy et al. 32 & Case-control \\
\hline & 28.70 & 295 & Osanai 43 & Case-control \\
\hline & 47.40 & 152 & Matuo et al. 45 & Case-control \\
\hline & 75.20 & 1,020 & Tessaro et al. 34 & Case-control \\
\hline
\end{tabular}

(continues) 
Table 2 (continued)

\begin{tabular}{|c|c|c|c|c|}
\hline Risk factor & Prevalence (\%) & Sample size & Study & Design \\
\hline \multicolumn{5}{|l|}{ Late first pregnancy: yes/no } \\
\hline$\geq 35$ years & 0.10 & 152 & Matuo et al. 45 & Case-control \\
\hline$\geq 30$ years & 6.60 & 76 & Paiva et al. 31 & Case-control \\
\hline$\geq 31$ years & 7.50 & 509 & Kalache et al. 22 & Case-control \\
\hline$\geq 31$ years & 7.60 & 1,020 & Tessaro et al. 34 & Case-control \\
\hline$\geq 30$ years & 7.80 & 348 & Hardy et al. 32 & Case-control \\
\hline$\geq 30$ years & 9.50 & 377 & Mendonça 20 & Case-control \\
\hline$>35$ years & 17.10 & 3,209 & Lamas \& Pereira 26 & Cross-sectional \\
\hline \multirow[t]{12}{*}{ Nulliparity: yes/no } & 8.90 & 348 & Hardy et al. 32 & Case-control \\
\hline & 9.20 & 152 & Matuo et al. 45 & Case-control \\
\hline & 9.60 & 1,020 & Tessaro et al. 34 & Case-control \\
\hline & 10.50 & 76 & Paiva et al. 31 & Case-control \\
\hline & 12.20 & 222 & Souza et al. 33 & Case-control \\
\hline & 12.50 & 377 & Mendonça 20 & Case-control \\
\hline & 13.30 & 256 & Amorim et al. 46 & Case-control \\
\hline & 14.10 & 509 & Kalache et al. 22 & Case-control \\
\hline & 14.20 & 330 & Lima et al. 19 & Cross-sectional \\
\hline & 15.00 & 3,209 & Lamas \& Pereira 26 & Cross-sectional \\
\hline & 16.50 & 164,269 & Lima \& Falk 25 & Cross-sectional \\
\hline & 50.80 & 295 & Osanai 43 & Case-control \\
\hline \multirow[t]{7}{*}{ No breastfeeding: yes/no } & 9.40 & 295 & Osanai 43 & Case-control \\
\hline & 14.90 & 348 & Hardy et al. 32 & Case-control \\
\hline & 15.10 & 152 & Matuo et al. 45 & Case-control \\
\hline & 19.50 & 1,020 & Tessaro et al. 34 & Case-control \\
\hline & 19.90 & 377 & Mendonça 20 & Case-control \\
\hline & 31.90 & 3,209 & Lamas \& Pereira 26 & Cross-sectional \\
\hline & 46.00 & 76 & Paiva et al. 31 & Case-control \\
\hline \multirow[t]{6}{*}{ History of abortion: yes/no } & 1.40 & 330 & Lima et al. 19 & Cross-sectional \\
\hline & 11.40 & 76 & Paiva et al. 31 & Case-control \\
\hline & $35.00 / 26.20^{*}$ & 164,269 & Lima \& Falk 25 & Cross-sectional \\
\hline & 37.30 & 1,020 & Tessaro et al. 34 & Case-control \\
\hline & $26.20 / 41.40 * \star$ & 295 & Osanai 43 & Case-control \\
\hline & 53.90 & 377 & Mendonça 20 & Case-control \\
\hline \multirow[t]{5}{*}{ Smoking: yes/no } & 1.50 & 40 & Lima et al. 19 & Cross-sectional \\
\hline & 7.00 & 330 & Lima et al. 19 & Cross-sectional \\
\hline & 13.50 & 377 & Mendonça 20 & Case-control \\
\hline & 24.00 & 164,269 & Lima \& Falk 25 & Cross-sectional \\
\hline & 34.40 & 256 & Amorim et al. 46 & Case-control \\
\hline
\end{tabular}

* Total abortions / induced abortions.

** Spontaneous abortions / induced abortions. 
of 11 of which consisted of fewer than 400 women. Such samples were too small to precisely detect risk factors with low prevalence rates, such as history of breast cancer in firstdegree relatives.

The second limitation is the background population from which the controls were obtained, where nearly $50.0 \%$ of the groups were patients who were hospitalized or under outpatient treatment for various diseases. Individuals with such characteristics present logistic advantages and availability for the studies and tend to recall their exposures and living characteristics more accurately than those who are apparently healthy. However, hospital-based controls may have diseases that share some risk factors with those being investigated for breast cancer, such as smoking, alcohol abuse, use of oral contraceptives, obesity, and others. Such factors may also thus be overrepresented in these samples, generating higher prevalence estimates than in the overall population 8,27 . The current review found few studies that had excluded individuals with diseases related to these risk factors from their controls.

A third limitation relates to matching, which can introduce a bias whereby controls differ from the basic population because they are similar to the cases in relation to the variables used in the matching. This effect can compromise the use of controls as representative of a given population in relation to the prevalence of the matched variable or other related factors 27 .

Despite these methodological problems, an advantage identified in this review was that in the majority of the studies, the data were collected through interviews prepared according to the specific objectives. This measure can minimize information errors and limitations that are present when the data are collected from existing registries or files 8 .

As for the most frequently investigated risk factors, we note a wide variation in the estimates. The heterogeneity of the samples may have contributed to this phenomenon. However, some findings merit specific comments. Initially, a first-degree family history of breast cancer, in addition to advanced age, is the most widely known and well-established high-risk factor for breast cancer. Risk is particularly increased if the disease in the family member occurred before menopause, and is apparently due to genetic factors 5,28,29.

According to cross-sectional studies in the United States with populations of adult women, some $5.0 \%$ to $10.0 \%$ presented a first-degree family history of breast cancer 30 . However, little is known about the prevalence of this factor in the Brazilian population. Higher prevalence rates than these, as for example in the study by Paiva et al. 31 , which was $13.10 \%$, should be analyzed with caution, because the finding may be due to chance or methodological characteristics. For example, the study by Mendonça 20, including hospital visitors in the controls, estimated a $9.8 \%$ prevalence rate for first-degree family history of breast cancer in this group; however, when the author analyzed a second model, in which visitors of parents hospitalized for breast cancer were excluded, the prevalence rate dropped to $3.7 \%$, a figure much more similar to those found in the studies by Hardy et al. 32 and Souza et al. 33 , which were $3.5 \%$ and $2.7 \%$, respectively.

Another noteworthy finding was the high prevalence $(75.0 \%)$ in the use of oral contraceptives (OC) among controls in the study by Tessaro et al. 34, in Pelotas, Rio Grande do Sul State. A survey in 1992 by Costa et al. 35 in the same city, with 677 women ages 20 to 49 years, found a prevalence of $66.5 \%$ of oral contraceptive use, which is also high. This may be a characteristic of the women in the region, because another survey, in the city of São Paulo, São Paulo State, in the same year, by Schor et al. 36, with 1,157 women ages 10 to 49 years, estimated a prevalence of only $35.3 \%$ for oral contraceptive use.

The association between oral contraceptives and breast cancer has still not been firmly established, but it has gained increasing scientific support 5 . Some studies with young women have demonstrated that prolonged OC use increases the risk of the disease in women $<45$ years of age 37 . The biological explanation for this effect is that oral contraceptives increase the proliferation of both normal epithelial cells and malignant cells already present in the breast tissue 38 . Therefore, OC use by a large number of women in some regions of Brazil merits more adequate surveillance of a possible increase in the risk not only of breast cancer, but also of other diseases.

A third highly interesting finding in this study relates to the high frequency of history of abortion. Some two-thirds of the studies that investigated the factor showed prevalence rates of $35.0 \%$ to $53.9 \%$. On the other hand, a retrospective study by Reis et al. 39 in hospitals in the cities of Fortaleza (Ceará), Recife (Pernambuco), Curitiba (Paraná), Rio de Janeiro (Rio de Janeiro), and Campinas (São Paulo), from 1992 to 1993, with 4,408 women, showed a prevalence of $19.0 \%$ of history of induced abortion, a figure which the authors considered quite high at the time.

Interruption of early pregnancy, when the breast tissue contains high concentrations of 
estrogens, may favor the proliferation of malignant cells. However, this association is still being investigated, and the slight increase observed in risk of the disease appears to be related to certain sub-groups, such as nulliparous women or those who had children but were exposed to the factor before the first full-term pregnancy 40 . Contrary to other risk factors (which require prolonged exposure in order to alter risk of the disease), with abortion a single exposure is sufficient. The main concern is that if the association between this risk factor and breast cancer is confirmed, the high prevalence of abortion could have an important public health impact, due to the excess cases of the disease that could be related to it 41 .

Some limitations in the current review should also be considered. The first relates to the small number of studies reviewed. Although the literature search was done in databases with a high probability of finding Brazilian studies, it may have been jeopardized by the strategies used, such as key words and limiting the search to the advanced form. Although the bibliographic references from the previously selected articles failed to add to the number of studies, this may have occurred due to publication bias, since there is a tendency not to publish studies in which the results are non-significant 42 .

A second limitation was that because of the heterogeneity in the samples studied, no summary mean was calculated for the prevalence of risk factors. Brazil is a country with continental dimensions and with numerous population differences between its regions and States. Although most of the studies came from cities in the Southeast region, different characteristics in the groups studied may also have resulted from geographic differences. Another aspect that contributed to the wide variation in the groups was the definition or classification of risk factor. Some numerical variables such as age at menarche and age at first gestation had different cutoffs among the studies, which may have influenced the estimate of their respective prevalence rates.

A third limitation was the nature of the studies themselves. Most of the studies were casecontrols, a design that is highly subject to selection bias, especially among controls. Due to problems already discussed in this area, one cannot guarantee that the control groups analyzed here were representative of their background populations. In addition, these studies were conducted with the purpose of investigating risk factors specifically for breast cancer, and this may have introduced some bias into the characteristics of the samples. It is possible that if a review were done on studies of risk factors for various diseases, but which are also related to breast cancer, the estimates of their prevalence rates may have differed from those found in the studies analyzed here.

Finally, analysis of the data reliability was satisfactory and significant. This shows that the frequencies of risk factors for breast cancer were presented clearly and objectively in the results of the studies. Still, it would be more appropriate if the data had been collected by two observers, and not only one, as in the case of this review.

We believe that this review has shed new light on the determinants of breast cancer in Brazilian women, for example in the high prevalence of abortion and oral contraceptive use in some groups. Still, given the limitations discussed above, we feel that the prevalence rates found in the studies in this review should not be generalized to the overall population, and they are thus hardly adequate as parameters for the development of health policies. Therefore it will be necessary to develop more surveys as well as longitudinal studies that are carefully designed for this population. Although no primary prevention exists for this disease, adequate identification of groups with risk factors that can be altered will be highly important for controlling this public health problem in Brazil. 


\section{Resumo}

Uma revisão sistemática de estudos foi realizada com o objetivo de conhecer as características da pesquisa epidemiológica sobre fatores de risco para câncer de mama em amostras de mulheres da população geral no Brasil. Dos 23 artigos identificados somente 14 foram selecionados. A maior parte deles foi oriunda da Região Sudeste do país. Três eram seccionais, desenvolvidos em populações muito específicas, e 11 eram do tipo caso-controle. O tamanho das amostras variou de 40 a 164.269 mulheres. Foram pesquisados ao todo, 29 fatores de risco, e dentre estes, 11 foram investigados em quatro ou mais estudos. A nuliparidade foi o fator mais freqüente, estando presente em 12 deles. As prevalências para estes fatores variaram grandemente entre as amostras, e como estas eram heterogêneas e os estudos tinham algumas limitações metodológicas, não se calculou uma medida-sumário para as mesmas.

Fatores de Risco; Neoplasias Mamárias; Literatura de Revisão

\section{Contributors}

V. F. S. Pinho was responsible for the literature review and contributed to the drafting of the article, together with E. S. F. Coutinho.

\section{Acknowledgments}

The authors wish to thank Professors Gulnar de Azevedo e Silva Mendonça (Institute of Social Medicine, State University of Rio de Janeiro) and Inês Mattos Echenique (National School of Public Health, Oswaldo Cruz Foundation/Rio de Janeiro) for their critical review of this article.

\section{References}

1. Instituto Nacional de Câncer. Estimativas da incidência e mortalidade por câncer 2003. Rio de Janeiro: Instituto Nacional de Câncer; 2003.

2. Departamento de Informática do SUS. Informações de saúde. Estatísticas vitais - mortalidade e nascidos vivos, 1980 a 2000. http://www.datasus. gov.br/ (accessed on Apr/2004).

3. Mahon SM. Cancer risk assessment: conceptual considerations for clinical practice. Oncol Nurs Forum 1998; 25:1535-47.

4. Bilimoria MM, Morrow M. The woman at increased risk for breast cancer: evaluation and management strategies. CA Cancer J Clin 1995; 45:263-78.

5. Meister K, Morgan J. Risk factors for breast cancer. New York: American Council on Science and Health; 2000. http://www.acsh.org (accessed on Feb/2002).

6. Kelsey JL, Horn-Ross PL. Breast cancer: magnitude of the problem and descriptive epidemiology. Epidemiol Rev 1993; 15:7-16.

7. Kelsey JL. Breast cancer epidemiology: summary and future directions. Epidemiol Rev 1993; 15: 258-63.

8. Silva IS. Cancer epidemiology: principles and methods. Lyon: International Agency for Research on Cancer; 1999.

9. Moreno AB, Lopes CS. Avaliação da qualidade de vida em pacientes laringectomizados: uma revisão sistemática. Cad Saúde Pública 2002; 18:81-92.

10. Hardy E, Faúndes A, Marussi EF, Algaba MFO, Pinotti JA. Aleitamento materno e câncer de mama. Estudo caso-controle desenvolvido em Campinas - SP. Rev Bras Ginecol Obstet 1983; 5:83-7.

11. Hardy E, Pinotti JA, Osis MJD, Faúndes A. Variáveis reprodutivas e risco para câncer de mama: estudo caso-controle desenvolvido no Brasil. Bol Oficina Sanit Panam 1993; 115:93-102.

12. Gomes ALRR, Guimarães MDC, Gomes CC, Chaves IG, Gobbi H, Camargos AF. A case-control study of risk factors for breast cancer in Brazil. Int J Epidemiol 1995; 24:292-9.

13. Mendonça GAS, Eluf-Neto J. Hospital visitors as controls in case-control studies. Rev Saúde Pública $2001 ; 35: 436-42$.

14. Matuo YK, Mamede MV, Villela M, Turatti ICC, Matuo T, Lopes JLC, et al. DDT no soro sangüíneo de mulheres e risco de câncer de mama. J Bras Ginecol 1998; 108:321-7.

15. Hsieh C, Trichopoulos D, Katsouyanni K, Yuasa S. Age at menarche, age at menopause, height and obesity as risk factors for breast cancer: associations and interactions in an international casecontrol study. Int J Cancer 1990; 46:796-800.

16. Pathak DR, Whittemore AS. Combined effects of body size, parity, and menstrual events on breast cancer incidence in seven countries. Am J Epidemiol 1992; 135:153-8.

17. Gomes ALRR, Guimarães MDC, Gomes CC, Chaves IG, Gobbi H, Camargos AF. Risk factors for breast cancer among pre- or post-menopausal women in Belo Horizonte, Brazil. Gynecol Obstet Invest 2001; 52:173-9.

18. Vieira MI, Silva SV, Chaves DNB, Petroianu A. Re- 
lação entre câncer de mama, amamentação e lateralidade cerebral. Rev Hosp Clin Fac Med Sao Paulo 1996; 51:85-9.

19. Lima MG, Koifman S, Scapulatempo IL, Peixoto M, Naomi S, Amaral MC. Fatores de risco para câncer de mama em mulheres indígenas Teréna de área rural, Estado do Mato Grosso do Sul, Brasil. Cad Saúde Pública 2001; 17:1537-44.

20. Mendonça GAS. Pesticidas e câncer de mama um estudo de caso-controle no Rio de Janeiro [Tese de Doutorado]. São Paulo: Universidade de São Paulo; 1997.

21. Vasconcelos AB, Mendonça GAS, Sichieri R. Height, weight, weight change and risk of breast cancer in Rio de Janeiro, Brazil. Sao Paulo Med J 2001; 119:62-6.

22. Kalache A, Maguire A, Thompson SG. Age at last full-term pregnancy and risk of breast cancer. Lancet 1993; 341:33-6.

23. Hennekens $\mathrm{CH}$, Buring JE. Epidemiology in medicine. Philadelphia: Lippincott Williams \& Wilkins; 1987.

24. Coggon D, Rose G, Barker DJP. Epidemiology for the uninitiated. $4^{\text {th }}$ Ed. London: British Medical Journal Publishing Group; 2002.

25. Lima JQ, Falk JA. A importância da identificação dos fatores de risco na luta contra o câncer. 2a Ed. Recife: Sociedade Pernambucana de Combate ao Câncer; 1998.

26. Lamas JM, Pereira MG. Fatores de risco para o câncer de mama e para lesões pré-malignas em mulheres assintomáticas no Distrito Federal. Rev Bras Mastol 1999; 9:108-14.

27. Gordis L. Epidemiology. Philadelphia: W. B. Saunders Company; 1996.

28. Koifman RJ, Koifman S, Vieira RJ. Familial aggregation of breast/ovarian cancer: age of onset along subsequent generations in Brazil. Cad Saúde Pública 1998; 14 Suppl 3:181-5.

29. Jardines L, Haffty BG, Doroshow JH, Fisher P, Weitzel J, Theriault RL. Breast cancer overview. Risk factors, screening, genetic testing, and prevention. In: Pazdur R, Coia LR, Hoskins WJ, Wagman LD, editors. Cancer management - a multidisciplinary approach. http://www.cancernetwork.com/handbook/contents.htm (accessed on Feb/2002).

30. National Cancer Institute. Genetics of breast and ovarian cancer. Cancer genetics - Health professionals. http://www.nci.nih.gov/ (accessed on Feb/2000).

31. Paiva CE, Ribeiro BS, Godinho AA, Meirelles RSP, Silva EVGS, Marques GD, et al. Fatores de risco para câncer de mama em Juiz de Fora (MG): um estudo caso-controle. Rev Bras Cancerol 2002; 48:231-7.

32. Hardy EE, Pinotti JA, Algaba MFO, Osis MJD, Faundes A. Variáveis reprodutivas e risco para câncer de mama. Estudo caso-controle desenvolvido em Campinas, São Paulo. Rev Bras Ginecol Obstet 1989; 11:212-6.
33. Souza RM, Defferrari R, Lazzaron AR, Scherer L, Borba AA, Frasson AL. Relação da história familiar em primeiro grau com câncer de mama. Rev Bras Mastol 1998; 8:123-8.

34. Tessaro S, Béria JU, Tomasi E, Barros AJD. Contraceptivos orais e câncer de mama: estudo de casos e controles. Rev Saúde Pública 2001; 35:32-8.

35. Costa JSD, D'Elia PB, Moreira MR. Prevalência de uso de métodos contraceptivos e adequação do uso de anticoncepcionais orais na cidade de Pelotas, Rio Grande do Sul, Brasil. Cad Saúde Pública $1996 ; 12: 339-44$.

36. Schor N, Ferreira AF, Machado VL, França AP, Pirotta KCM, Alvarenga AT, et al. Mulher e anticoncepção: conhecimento e uso de métodos anticoncepcionais. Cad Saúde Pública 2000; 16:37784.

37. Malone KE, Daling JR, Weiss NS. Oral contraceptives in relation to breast cancer. Epidemiol Rev 1993; 15:80-97.

38. Schlesselman JJ. Net effect of oral contraceptive use on the risk of cancer in women in the United States. Obstet Gynecol 1995; 85:793-801.

39. Reis AFF, Costa CFF, Mello CR, Almeida FML, Costa HLFF, Gabiatti JRE, et al. Estudo epidemiológico do abortamento no Brasil. Rev Bras Ginecol Obstet 1995; 17:453-61

40. Canty L. Breast cancer risk: protective effect of an early first full-term pregnancy versus increased risk of induced abortion. Oncol Nurs Forum 1997; 24:1025-31.

41. Brind J, Chinchilli VM, Severs WB, Summy-Long J. Induced abortion as an independent risk factor for breast cancer: a comprehensive review and meta-analysis. J Epidemiol Community Health 1996; 50:481-96.

42. Coutinho ESF. Meta-análise. In: Medronho RA, editor. Epidemiologia. Rio de Janeiro: Atheneu; 2002. p. 447-57.

43. Osanai MW. Fatores de risco de câncer de mama em pacientes do Instituto Nacional de Câncer do Rio de Janeiro 1976-1977 [Dissertação de Mestrado]. Rio de Janeiro: Escola Nacional de Saúde Pública, Fundação Oswaldo Cruz; 1984.

44. Barros ACSD, Motta EV, Bunduky V, Melo NR, Souza AZ, Pinotti JA. Estudo do perfil lipídico em mulheres com câncer de mama. Rev Bras Ginecol Obstet 1996; 18:201-6.

45. Matuo YK, Mamede MV, Clapis MJ, Turatti ICC, Matuo T, Lopes JLC, et al. Níveis de DDT no soro de mulheres e risco de câncer de mama na região de Ribeirão Preto, Brasil. Rev Bras Toxicol 2000; 13:5-15.

46. Amorim LMF, Rossini A, Mendonça GAS, Lotsch PF, Simão TA, Gallo CVM, et al. CYP1A1, GSTM1, and GSTT1 polymorphisms and breast cancer risk in Brazilian women. Cancer Lett 2002; 181: $179-86$.

Submitted on 17/Aug/2004 Approved on 01/Sep/2004 